\title{
Slag Rim Formation of two Mould Powders used for Casting of Construction Steel
}

\author{
Irmtraud Marschall1,2, Guangmin Xia ${ }^{3}$, and Nathalie Kölbl ${ }^{2}$ \\ ${ }^{1} \mathrm{~K} 1-\mathrm{MET} \mathrm{GmbH}$, Leoben, Austria \\ ${ }^{2}$ Chair of Ceramics, Department Mineral Resources and Petroleum Engineering, Montanuniversitaet Leoben, \\ Leoben, Austria \\ ${ }^{3}$ voestalpine Stahl GmbH, Linz, Austria
}

Received October 31, 2017; accepted November 15, 2017; published online December 11, 2017

\begin{abstract}
Two different mould powders are used for casting peritectic steel grades at the voestalpine Stahl Linz GmbH slab casting machine. Powder A forms significantly larger slag rims than Powder B, although their chemical compositions are very similar.

For the clarification of the different performance during service, the melting and solidification behaviour as well as the viscosity of the original mould powders have been investigated. Slag rim samples were taken during tail out and cross-sections were analysed by microscopic means.

The findings show that the mould powder suppliers use two different raw material concepts. Consequently, the powders do not exhibit identical melting behaviour, which turns out to be the main influencing factor for the slag rim formation.
\end{abstract}

Keywords: Mould powder, Slag rim, Melting, Solidification

Schlackenkranzbildung zweier Gießpulver beim Vergießen peritektischer Stahlgüten

Zusammenfassung: Für das Vergießen peritektischer Stahlgüten werden bei voestalpine Stahl Linz $\mathrm{GmbH}$ zwei verschiedene Stahlgüten eingesetzt. Hierbei bildet Pulver A signifikant größere Schlackenkränze als Pulver B, obwohl ihre chemische Zusammensetzung nahezu ident ist.

Zur Klärung dieses unterschiedlichen Verhaltens wurden das Schmelz- und Erstarrungsverhalten sowie die Viskosität der Originalpulver untersucht. Schlackenkranzproben

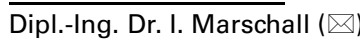

Chair of Ceramics, Department Mineral Resources and Petroleum Engineering,

Montanuniversitaet Leoben,

Leoben, Austria

irmtraud.marschall@unileoben.ac.at wurden während des Ausfahrens gezogen und mikroskopisch untersucht.

Die Untersuchungen ergaben, dass die Gießpulverlieferanten zwei verschiedene Rohstoffkonzepte verwenden. Aus diesem Grund zeigen diese Pulver ein unterschiedliches Aufschmelzverhalten, welches maßgeblich für die Ausbildung von Schlackenkränzen verantwortlich ist.

Schlüsselwörter: Gießpulver, Schlackenkranz, Aufschmelzen, Erstarren

\section{Introduction}

In steel casting operations employing mould powders, usually a crust on the mould in the meniscus region, called slag rim, is formed. This slag rim is attached to the copper mould and moves downwards with the mould oscillation [1]. Its thickness has a strong impact on the heat flux and a large influence on the initial shell formation. In order to achieve a steady state condition of the solidification process and the desired surface quality of the strand, the size of the slag rim should be stable and robust during the whole casting $[2,3]$. Rims have been found to show a layered structure of mould slag, small intermediate phases, and original mould powder. They also include carbon black particles [4,5]. It is mentioned that, during the upward mould motion, the bottom part of the slag rim is coated by liquid and solid powder. During the downward mould motion, this new powder layer melts when coming into contact with the hot steel meniscus. Thus, the infiltrated slag layer and the bottom part of the rim are renewed [6,7]. According to Takawa [8], the temperature at the interface slag rim-slag lies around $1080^{\circ} \mathrm{C}$. In a previous study, it turned out that the chemical compositions of the mould powders show a deep impact on the slag rim size [9]. Even though the samples investigated in the present studies are very similar in their chemical com- 


\begin{tabular}{|c|c|c|c|c|c|c|c|c|c|}
\hline Powder & $\mathrm{F}$ & $\mathrm{Na}_{2} \mathrm{O}$ & $\mathrm{MgO}$ & $\mathrm{Al}_{2} \mathrm{O}_{3}$ & $\mathrm{SiO}_{2}$ & $\mathrm{CaO}$ & $\mathrm{MnO}$ & $\mathrm{C}$ & $\mathrm{CaO} / \mathrm{SiO}_{2}$ \\
\hline$A$ & 8.2 & 8.0 & 2.0 & 3.4 & 30.9 & 38.6 & 0.0 & 6.0 & 1.25 \\
\hline B & 8.1 & 6.8 & 1.2 & 4.7 & 31.8 & 38.1 & 1.0 & 5.9 & 1.20 \\
\hline
\end{tabular}

Fig. 1: Slag rim samples after service
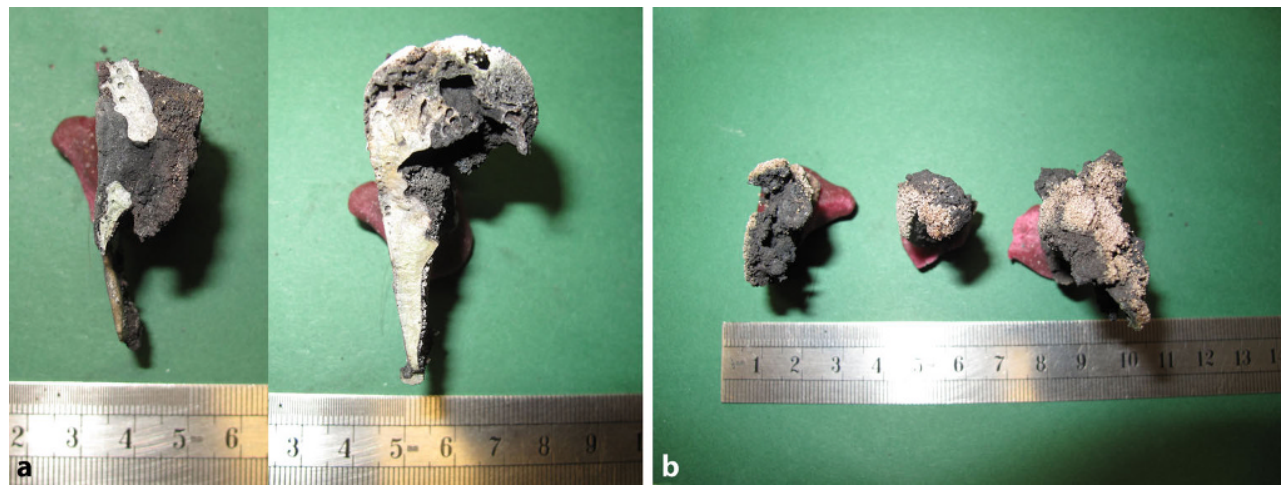

positions, Powder A tends to form larger slag rims during operation than Powder B.

\section{Samples}

Two mould powders from different suppliers but with almost similar chemical compositions (Table 1) are used for casting peritectic steel grades at the voestalpine Stahl Linz $\mathrm{GmbH}$ slab casting machine. Slag rim samples collected during tail out (Fig. 1) and samples from the corresponding mould powders have been analysed.

\section{Experimental Procedure}

The mineralogical compositions of the mould powders have been analysed by X-ray diffraction (XRD), and polished sections have been investigated with reflected light microscopy and scanning electron microscopy (SEM). For the investigation of the melting behaviour, Simultaneous Thermal Analyses (STA) have been performed. $100 \mathrm{mg}$ of mould powder as delivered were heated to $1350^{\circ} \mathrm{C}$ at a rate of $5^{\circ} \mathrm{C} \cdot \mathrm{min}^{-1}$ within a platinum crucible using synthetic air for purging. For the analysis of the microstructure during heating, the mould powders were annealed within steel crucibles $\left(30 \times 30 \times 40 \mathrm{~mm}^{3}\right)$ at $1000^{\circ} \mathrm{C}, 1100^{\circ} \mathrm{C}$, and $1200^{\circ} \mathrm{C}$ using a preheated high temperature chamber furnace. After a dwell time of $15 \mathrm{~min}$, the samples were quenched within the crucibles to room temperature. Then the specimens were analysed by XRD and microscopic means.

For the investigations of the solidification behaviour and the viscosity for decarburisation, the specimens were annealed at $700^{\circ} \mathrm{C}$ for $12 \mathrm{~h}$. Afterwards the samples were melted in covered platinum crucibles at $1400^{\circ} \mathrm{C}$ for $15 \mathrm{~min}$, poured onto a steel plate at room temperature, and sprinkled with cold water to obtain glassy pieces. Finally, the samples were ground into powder and split up for the consecutive tests.

The solidification behaviour has been determined by the Furnace Crystallisation Test (FCT). This test is a big scale Differential Thermal Analysis performed in a high temperature chamber furnace. Sample weights of $27 \mathrm{~g}$ were put into one platinum crucible and the equal mass of alumina was used as a reference material in a second crucible. The crucibles were heated to $1350^{\circ} \mathrm{C}$, held for $15 \mathrm{~min}$, and cooled to room temperature at a cooling rate of $10^{\circ} \mathrm{C} / \mathrm{min}$. The temperatures of the mould powder and the alumina were measured with type $S$ thermocouples situated within the samples and recorded via a data logger at intervals of $30 \mathrm{~s}$. After this procedure the solidified specimen was cut close to the platinum wire into two pieces, analysed by XRD, polished, and investigated by microscopic means.

The dynamic viscosities and the break temperatures of the Fluxes $A$ and $B$ were measured with a commercial high temperature rotational viscometer. The crucible as well as the bob were made of platinum. $27 \mathrm{~g}$ of the sample were heated within $30 \mathrm{~min}$ to $1450^{\circ} \mathrm{C}$, and the measurement was carried out at a cooling rate of $10^{\circ} \mathrm{C} \cdot \mathrm{min}^{-1}$ with a rotational speed of $150 \mathrm{rpm}$. During the experiment, the furnace chamber was purged with argon.

From the slag rim samples, polished sections have been prepared and analysed with respect to their mineralogical composition in dependence on the position within the slag rim.

\section{Results and Discussion}

\subsection{Characterisation of the Mould Powders}

\subsubsection{Raw Materials}

Even though the chemical compositions of both mould powders are almost similar, the composition of the raw ma- 


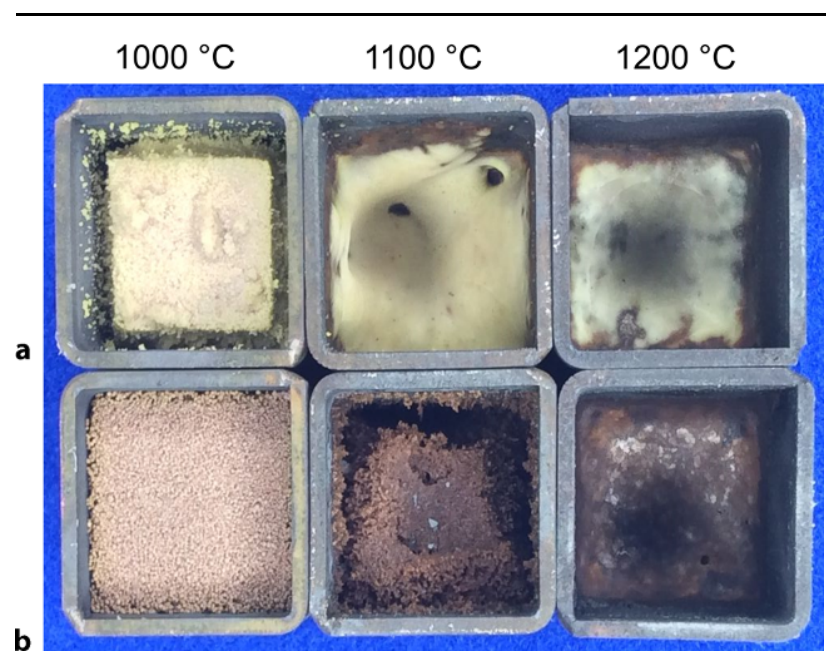

Fig. 2: Mould Powders A and B after annealing at different temperatures and quenching to room temperature

terials differs. Powder $A$ is based on a crystallised fluorine containing slag consisting of wollastonite $\left(\mathrm{CaSiO}_{3}\right)$, cuspidine $\left(\mathrm{Ca}_{4} \mathrm{SiO}_{7} \mathrm{~F}_{2}\right)$, and small amounts of oldhamite (CaS) besides a residual glassy phase. Quartz $\left(\mathrm{SiO}_{2}\right)$, fluorite $\left(\mathrm{CaF}_{2}\right)$, spodumene $\left(\mathrm{LiAIS}_{2} \mathrm{O}_{6}\right)$, and several carbon carriers are added secondarily. The granules contain some amount of gaylussite $\left(\mathrm{Na}_{2} \mathrm{Ca}\left(\mathrm{CO}_{3}\right)_{2} \cdot 5 \mathrm{H}_{2} \mathrm{O}\right)$. Sporadic particles of fly-ash, alumina $\left(\mathrm{Al}_{2} \mathrm{O}_{3}\right)$, natural wollastonite, diopside $\left(\mathrm{CaMgSi}_{2} \mathrm{O}_{6}\right)$, and calcite $\left(\mathrm{CaCO}_{3}\right)$ have been observed, too.

By contrast, the main components of Powder B are natural wollastonite, fluorite, and fly ash. Calcite, quartz, and several carbon carriers are used in minor amounts. From the results of the STA, it can be concluded that the carbon carriers of Powder B and their amounts differ from those of Powder A. Diopside, pyrolusite $\left(\mathrm{MnO}_{2}\right)$, alumina, and hematite $\left(\mathrm{Fe}_{2} \mathrm{O}_{3}\right)$ have been detected occasionally.

\subsubsection{Melting Behaviour}

From the STA results, it follows that the diverse mould powder recipes lead to a different melting behaviour. Up to $580^{\circ} \mathrm{C}$, the combustion of carbon is the predominant reaction, but, different to mould Powder A, Powder B contains another carbon carrier with an exothermal peak at $717^{\circ} \mathrm{C}$. The dissociation of the carbonates takes place for Powder $A$ between 581 and $720^{\circ} \mathrm{C}$, but for Powder $\mathrm{B}$ this reaction finishes around $602{ }^{\circ} \mathrm{C}$. At $772{ }^{\circ} \mathrm{C}$ a peak originating from the reduction of the pyrolusite is visible in the curve of Powder B. The curves exhibit large differences in the formation of liquid. Due to the diffusion processes of sodium into the glassy phase of the slag of Sample $A$, the first liquid phase is formed at $740{ }^{\circ} \mathrm{C}$, whereas the main melting process starts at higher temperatures $\left(990^{\circ} \mathrm{C}\right)$. At $1062^{\circ} \mathrm{C}$ and $1223^{\circ} \mathrm{C}$, two peak maxima are visible until the powder is completely liquefied at $1299^{\circ} \mathrm{C}$. By contrast, no such first liquid formation is visible in the DTA curve of Powder B. Its melting process starts at $1073^{\circ} \mathrm{C}$ and ends at $1224^{\circ} \mathrm{C}$. The temperature of the total liquefaction of Sample B corresponds to the same temperature related to the largest melting peak of Powder $A$.
This different melting behaviour of the mould powders is also confirmed by the annealing experiments (Fig. 2). While for Powder $\mathrm{B}$ granules are still visible after annealing at $1000^{\circ} \mathrm{C}$, Powder A forms a compact cube at $1000^{\circ} \mathrm{C}$. From $1000^{\circ} \mathrm{C}$ on, cuspidine is the main mineral phase for both powders, but its crystal size is always larger for Powder $A$ (Fig. 3). After annealing at $1000^{\circ} \mathrm{C}$, residues of alumina are present. In case of Powder $A$, this alumina is surrounded by lazurite $\left(\mathrm{Na}_{7} \mathrm{Al}_{6} \mathrm{Si}_{6} \mathrm{O}_{24} \mathrm{~S}_{3}\right)$ due to its higher sulphur content, whereas for Powder $\mathrm{B}$ nepheline $\left(\mathrm{K}_{0.25} \mathrm{Na}_{6} \mathrm{Al}_{6.24} \mathrm{Si}_{9.76} \mathrm{O}_{32}\right)$ is present in contact with alumina. However, fluorite segregated at $1200^{\circ} \mathrm{C}$ from the liquid phase only for Powder B.

\subsubsection{Viscosity and Solidification}

The mean viscosities at $1300^{\circ} \mathrm{C}$ are $0.042 \pm 0.003$ Pas for $A$ and $0.062 \pm 0.006$ Pas for B. Due to their similar chemical compositions, the Break Temperatures of $1212 \pm 4^{\circ} \mathrm{C}$ for Sample A and $1213 \pm 6^{\circ} \mathrm{C}$ for Sample B are almost identical. The crystallisation temperatures detected with the FCT are in the same range: $1184^{\circ} \mathrm{C}$ for Sample $A$ and $1196{ }^{\circ} \mathrm{C}$ for Samples B. In both samples cuspidine is the main phase, similar to the melting process. The lower viscosity of Sample A supports the formation of bigger crystal compared to those of Slag B [10]. Furthermore, the matrix of both samples is different (see Fig. 4). Apart from cuspidine, crydtallised $\mathrm{NaAlF}_{4}$ and only small amounts of glassy phase have been observed for Sample A. For Sample B, by contrast, the amount of glassy phase was considerable higher and small amounts of fluorite and villiaumite $(\mathrm{NaF})$ segregated out of the liquid.

\subsection{Slag Rims}

Depending on the mould powder, the shape of the slag rims taken during tale out differs. As can be seen from Fig. 5, Powder A forms large bulgy slag rims, whereas the slag rims of Powder $B$ are considerably smaller (Fig. 5). For Slag $\operatorname{Rim} A$, the significant increase of the $\mathrm{CaO} / \mathrm{SiO}_{2}$ ratio in the centre and the lower parts (marked boundaries in Fig. 5) is remarkable. The $\mathrm{CaO} / \mathrm{SiO}_{2}$ ratio detected by $\mathrm{EDX}$ in the samples annealed at $1200^{\circ} \mathrm{C}$ is 1.09 : In the middle of the slag rim bulge, it increases to 1.20 , and a maximum of 1.37 can be observed at the lower parts. Simultaneously, the sodium content is decreased by 1-2 wt. Yet, the surrounding areas, marked in Fig. 6 , are enriched in sodium and fluorine. From this it can be concluded that the liquidus temperature of the centre part is higher than that of the original mould powder and will not melt easily during service. By contrast, the chemical element distribution of Slag Rim B is homogeneous over the whole cross section.

The information about the formation of the slag rims is derived from the slag rims' texture. In $\operatorname{Rim} A$, areas with a high concentration of carbon surround the bulges. In Fig. 6 these areas are marked. For Powder B by contrast, such areas can only be observed in contact with the mould. In both slag rims, residual carbon particles as well as pores evolving from gas formation due to the combustion of these carbon particles are entrapped in sintered areas. In Slag 


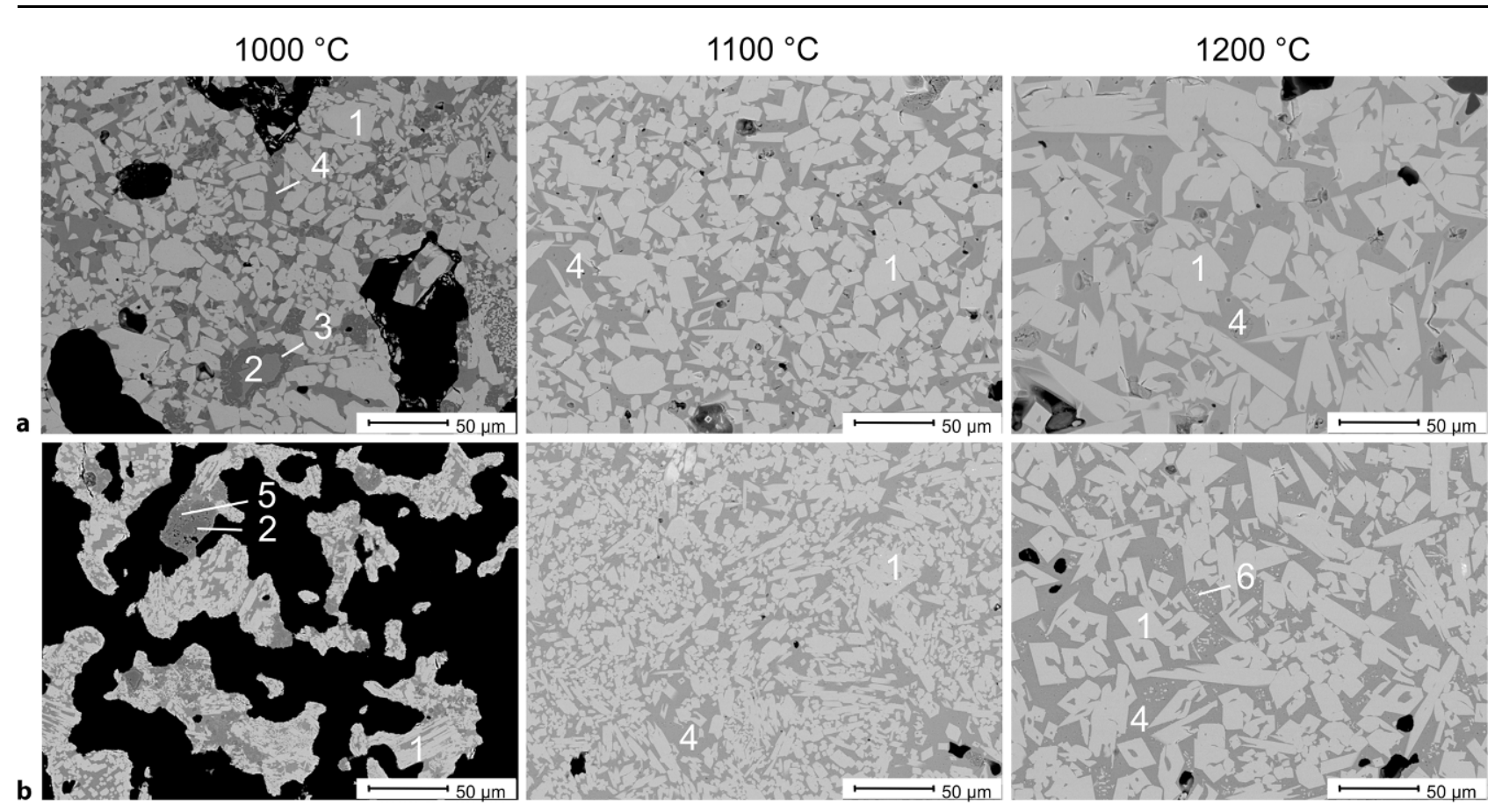

Fig. 3: Back scatter electron image of Mould Powders $A$ and $B$ after annealing at different temperatures. 1 cuspidine $\left(\mathrm{Ca}_{4} \mathrm{Si}_{2} \mathrm{O}_{7} \mathrm{~F}_{2}\right), 2 \mathrm{alumina}_{(}\left(\mathrm{Al}_{2} \mathrm{O}_{3}\right)$, 3 lazurite $\left(\mathrm{Na}_{7} \mathrm{Al}_{6} \mathrm{Si}_{6} \mathrm{O}_{24} \mathrm{~S}_{3}\right)$, 4 glassy phase, 5 nepheline $\left(\mathrm{NaAlSiO}_{4}\right)$, 6 fluorite $\left(\mathrm{CaF}_{2}\right)$

Fig. 4: Mould powder structure after furnace crystallisation test. 1 cuspidine $\left(\mathrm{Ca}_{4} \mathrm{Si}_{2} \mathrm{O}_{7} \mathrm{~F}_{2}\right), 2 \mathrm{NaAlF}_{4}$, 3 glassy phase, 4 fluorite $\left(\mathrm{CaF}_{2}\right)$, 5 villiaumite $(\mathrm{NaF})$
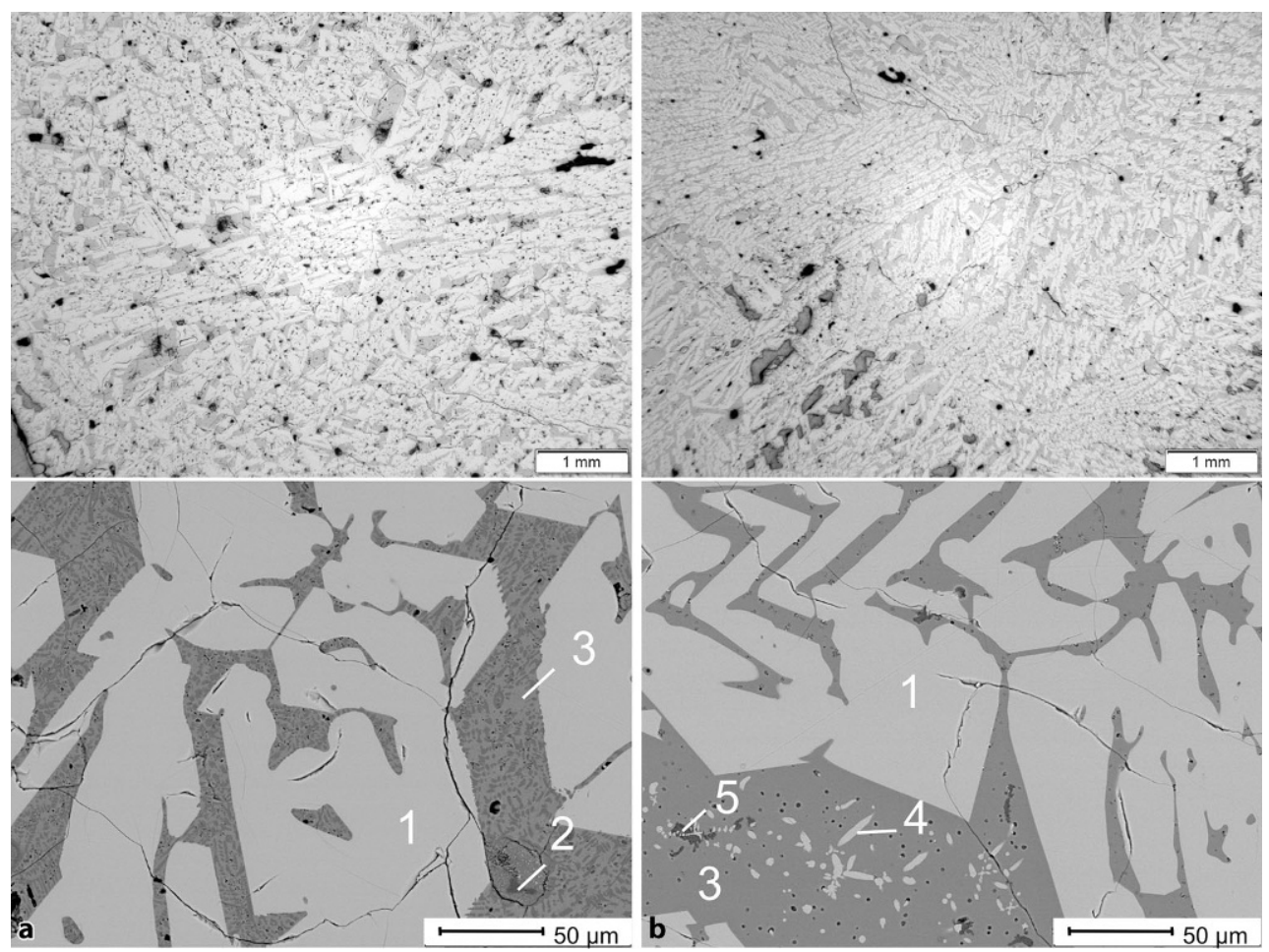

$\operatorname{Rim} A$, these pores are situated in the bulge, whereas for B the pores can be seen all over the cross section (Fig. 6). This gives strong evidence that these parts have been formed by sintered powder and not by liquid. For Powder B this is confirmed by the cuspidine crystal shape, which is similar to the samples fired at 1100 and $1200^{\circ} \mathrm{C}$ (see Figs. 3 and 5). Areas corresponding to the quenched samples after a tem- perature treatment at $1000^{\circ} \mathrm{C}$ can only be seen in contact with the mould and do not take part in the mechanism, since the amount of liquid is too low for sticking the granules together sufficiently strong. It can be concluded that most of Slag Rim B is made of molten powder sintered between 1100 und $1200^{\circ} \mathrm{C}$ and that the painting mechanism [6] is responsible for the formation of the whole slag rim. 
Fig. 5: Slag rim textures. 1 cuspidine $\left(\mathrm{Ca}_{4} \mathrm{Si}_{2} \mathrm{O}_{7} \mathrm{~F}_{2}\right)$, 2 villiaumite (NaF), 3 nepheline (NaAlSiO4), 4glassy phase
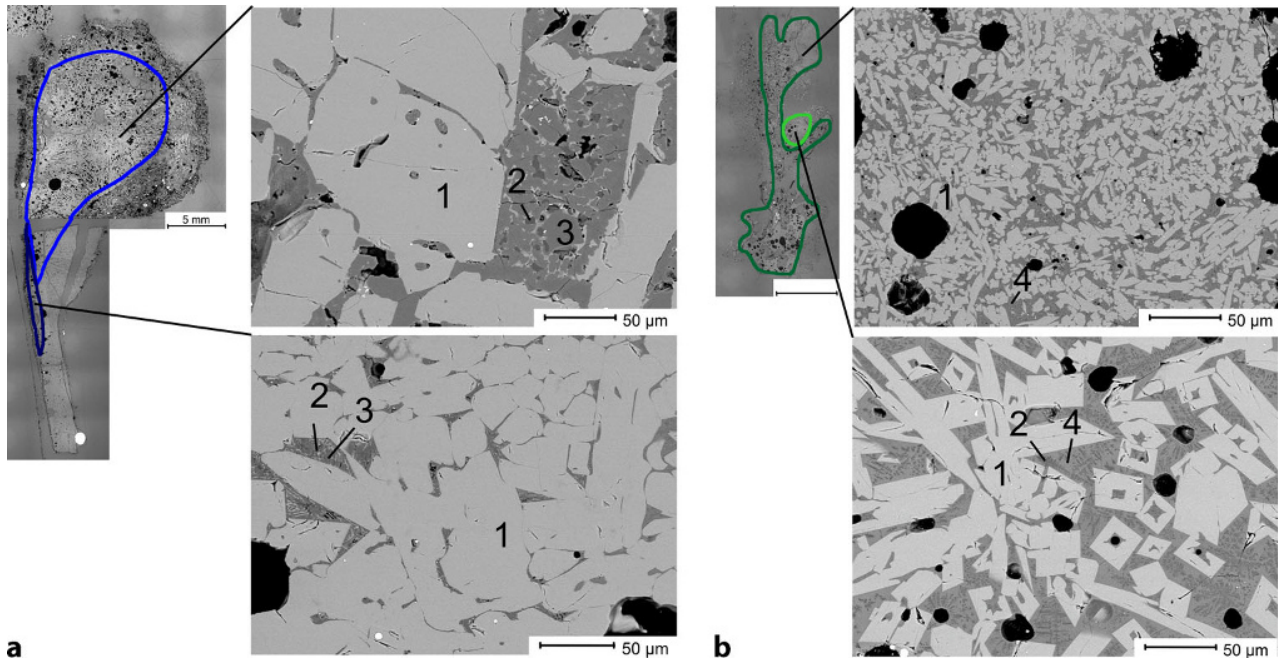

a

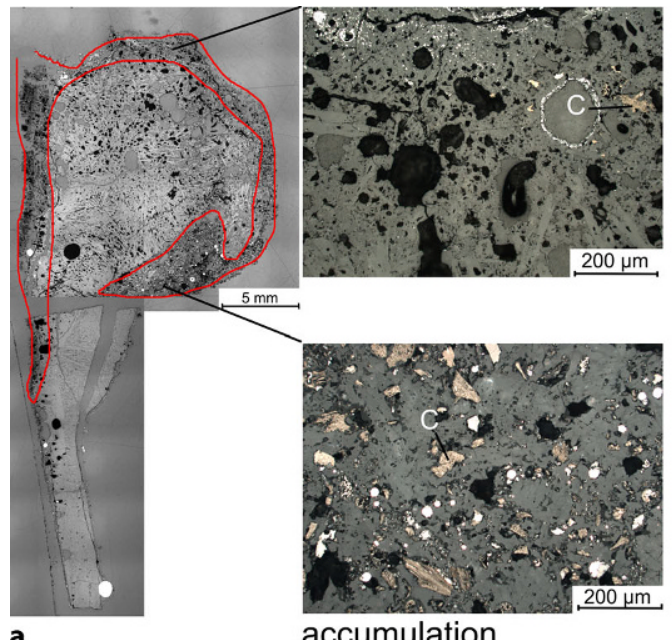

accumulation
Fig. 6: Carbon distribution in the slag rims (reflected light microscopy)
In the case of Powder A, the situation is more complex. The present carbon and spherical pores indicate that the bulge is mainly made of sintered powder, but the texture, especially in the centre of the bulge, looks like the crystallised samples. The cuspidine crystal size is extremely large, partially up to $2 \mathrm{~mm}$. This is explained by the formation of considerable amounts of liquid below $1000^{\circ} \mathrm{C}$. This liquid acts as a binder and promotes slag rim formation in the upper region. Furthermore, the liquid facilitates the diffusion processes and crystal growth of the cuspidine particles already present in the raw material. Even during the negative strip time, the temperatures are too low for the liquefaction of these cuspidine crystals. Moreover, it looks as if the remaining sodium and fluorine rich liquid as well as the carbon particles are squeezed out of the structure and accumulate next to the mould. As a consequence, the $\mathrm{C} / \mathrm{S}$ ratio and likewise the liquidus temperature in the centre part are increased. Due to this segregation, layers of $\mathrm{Ca}_{2} \mathrm{NaSiO}_{4} \mathrm{~F}$, villiaumite $(\mathrm{NaF})$, and carbon accumulation appear in the slag rim next to the mould. The lower part of the slag rim is probably made up of a mixture of liquid slag and powder sintered above $1100^{\circ} \mathrm{C}$. The low viscos- ity of Slag A supports the crystal growth rate. Segregation processes take place as well. As a consequence, even the lower parts do not liquefy easily during the negative strip time. For Slag Rim A, it can be concluded that the painting mechanism works, too. The slag rim, however, is not only built up by the attachment of liquid slag layers and powder sintered above $1100^{\circ} \mathrm{C}$ molten powder, but also by granules held together by liquid phases formed from $740{ }^{\circ} \mathrm{C}$ upwards. The large melting range of Powder $A$ is therefore responsible for the typical bulging shape of Slag $\operatorname{Rim} A$.

\section{Conclusion}

According to Perrot [6], "slag rim coalescence" is the main mechanism of slag rim growth. Its grows is especially fast if slag and semi-molten granules are involved. During service the slag acts as a "binder" between the granules. The mechanism requires low viscosities and a special ratio of liquid to non-molten granules. For Powder B this ratio seems to be too low and the viscosity too high. Therefore, its slag rim growth is decreased in this case. Comparing 
the melting behaviour of these mould powders, it can be concluded that the range of the melting temperature of the mould powder also influence the size of slag rims. If the melting range is small, smaller slag rims can be expected.

Funding. The research program of the "metallurgical competence center" (K1-MET) is supported within the Austrian program for competence centers COMET (Competence Center for Excellent Technologies). Moreover, this work was supported by the industrial partners voestalpine Stahl GmbH and RHI AG.

Funding. Open access funding provided by Montanuniversität Leoben.

Open Access This article is distributed under the terms of the Creative Commons Attribution 4.0 International License (http://creativecommons. $\mathrm{org} / \mathrm{licenses} / \mathrm{by} / 4.0 /$ ), which permits unrestricted use, distribution, and reproduction in any medium, provided you give appropriate credit to the original author(s) and the source, provide a link to the Creative Commons license, and indicate if changes were made.

\section{References}

1. Badri, A.; Natarajan, T. T.; Snyder, C.C.; K. Powers, D.; Mannion, F. J. Byrne, M.; Cramb, A.W.: A mould simulator for continuous casting of steel: Part II. The formation of oscillations marks during the continuous casting of low carbon steel, Metall. and Mat. Transaction B, 36 (2005), no. 3, p 373

2. Kromhout, J.; Boom, R.; Kawamoto, M.; Hanao, M.: Development of mould flux for high speed thin slab casting, in: Sanchez, M (ed.): Molten 2009, Proceedings of VIII International Conference on Molten Slags, Fluxes and Salts, Santiago, Chile, 2009, pp 1041-1052
3. Däcker, C.-Å.; Glaes, M.; Andersson, S. P.; Salwén, A.; Eggertson, C.: Influence of slag rim formation on intial solidification of stainless steel, in: Associazion Italiana di Metallurgia (ed.): ECCC6 ${ }^{\circ}$ Proceedings of 6th European Conference on Continuous Casting, Riccione, Italy, 2008

4. Kromhout, J. A.; Schimmel, R. C.: Understanding mould powders for high-speed casting, Ironmaking \& Steelmaking (2016), http:// www.tandfonline.com/doi/full/10.1080/03019233.2016.1257557 (6.4.2017)

5. Marschall, I.; Harmuth, H.: Investigation of slag rim growth in the continuous casting process, in: MEFO: Metallurgical Research Institute AB (ed.): Scanmet III, Proceedings $3^{\text {rd }}$ International Confernce on Process Development in Iron and Steelmaking, MEFOS, Luleå, Sweden, 2008, pp 419-427

6. Perrot, C.; Pontoire, J. N.; Marchionni, C; Ridolfi, M.R.; Samcho, L.F. Several slag rims and lubrication behaviours in slab casting, in: La Revue the Metallurgie (ed), ECCC2005, Proceedings of 5th European Continuous Casting Conference, La Revue de Métallurgie, Nice, France, 2005, pp 36-47

7. Schwerdtfeger, K.: Metallurgie des Stranggießens, Düsseldorf: Verl. Stahleisen, 1992

8. Takawa, T.; Takamoto, T.; Tomono H.; Tada, K.: Initial solidification analysis in the vicinity of meniscus in continuous casting mould, The Iron and Steel institute of Japan, 28 (1988), p. 70

9. Marschall, I.; Kölbl, N.; Harmuth, H.: Comparison of the slag rim formation of two different mould powders, in: ASM international (ed.) MS\&T 2010, Proceedings of the Materials Science \& Technology Conference Proceedings of the International Conference on Materials Science \& Technology, Houston, USA, 2010, p. 1591-1600

10. Vogel, W: Glaschemie, NewYork: Springer, 1992 